\title{
IBP': A New Index to Estimate Biogeographical Peculiarity
}

\author{
Roberto Pizzolotto and Pietro Brandmayr \\ Università della Calabria, Dipartimento Ecologia, 87036 Rende, Italy \\ Correspondence should be addressed to Roberto Pizzolotto; piz@unical.it
}

Received 2 October 2013; Accepted 27 October 2013; Published 8 January 2014

Academic Editors: R. Dodd and D. Sánchez-Fernández

Copyright (C) 2014 R. Pizzolotto and P. Brandmayr. This is an open access article distributed under the Creative Commons Attribution License, which permits unrestricted use, distribution, and reproduction in any medium, provided the original work is properly cited.

\begin{abstract}
The biogeographical peculiarity of a given geographical area is directly linked to the number of its endemic species. This paper aims to formulate an index directly linked to the biogeographical peculiarity of an area. A graphical model and an index of the biogeographical peculiarity are proposed, based on a cumulative sum (i.e., including all the amounts that were added previously). An example of the computations is proposed, based on the number of different types of geographical ranges (i.e., chorotypes) characterizing two different ecosystems; their biogeographical peculiarity of was evaluated on the basis of presence versus absence of carabid species. Both the graphical model and the index mirrored the different faunistic compositions of the ecosystems, because the index reached a higher value where more endemic species have been found. Our investigation has found a new method for evaluating the biogeographical peculiarity of a given area or biota in a simple way. The index could be used for either conservation biogeography (e.g., monitoring of biotic homogenization) or for theoretical studies integrating ecology and biogeography.
\end{abstract}

\section{Introduction}

The geographical distribution of living organisms is the result of cladogenesis combined with palaeogeographic events (e.g., continental drift) and palaeoclimatic events (e.g., ice ages) [1-3]. For a discussion on cladistic versus evolutionist see [4]. Furthermore, living organisms, whether or not they are undergoing the process of speciation, have to deal with changeable environmental factors (e.g., biotic interactions, human factors, realized ecological niche, and dispersal ability), where their power of adaptation is a decisive factor in determining their present distribution range [5].

The types of geographical range in a given area characterize the natural resources of that area not only taxonomically but also ecologically, because the geographical range of a species is directly linked to several morphofunctional traits of that species, which allow it to survive in a particular environment for sufficient time to cope with the constraints of evolution [6-9]. This is why the species distribution range is not simply a matter of squared kilometers, while it is reasonable to regard it as a biological characteristic of a species $[10,11]$. This way it is an important parameter to be taken into account, for example, in the evaluation of conservation protocols [12-15].

Similarities among geographical ranges make it possible to classify them into types called chorotypes, the sum of which gives the chorological spectrum of a given biota $[16,17]$. Each chorological spectrum is a sort of picture of the peculiarity of the taxa in that biota. It is usual to make comparisons among biota, or other geographical units, either from a quantitative point of view on the basis of the number of species belonging to each chorotype, or by a visual comparison of the chorological spectrum histograms [1821]. Generally, more attention appears to have been paid to endemic species [22] on the basis of either a subjective [21,23] or an objective criterion [24].

The aim of this paper is to propose a new method for comparing different biota, or ecogeographical units, based on the formulation of an index directly linked to the biogeographical peculiarity of the chorological spectrum in a given unit. Since a high biogeographical peculiarity is a property of a given biota when many species live only within that 
biota, for example, when there are many endemic species $[4,25]$, our aim is to find an index that integrates in a simple measure the weight of the endemic species compared against the weight of the other chorotypes.

From a biogeographical point of view, this index might be a valuable help in cases where, for example, two regions sheltering the same number of endemic species differ in species richness; furthermore it could aid in determining biogeographical peculiarities for conservation policies, for example, the preservation of endemism centres (see [26]) or the habitat conservation for avoiding species range contraction [27].

\section{Method}

The family of carabid beetles was used just as an example of how the index performs. In particular, attention was focused on Italian species. Carabids have been thoroughly studied from the taxonomical and biogeographical point of view, at least in Europe (see http://www.faunaeur.org/).

The Italian carabid fauna has several geographical ranges, which can be classified into chorotypes following [28]; see also [29].

The index presently proposed is based on that of [30], applied by [31-38]. In the present paper the index proposed by [30] has been implemented for avoiding the possibility of getting inaccurate results.

2.1. Data Organization Prerequisites. For the index computation it is necessary to first classify the biological distinctiveness of an area. This is why we have grouped the chorotypes into chorological categories based on their degree of peculiarity, where a high biogeographical peculiarity is a property of a given biota when many species live only within that biota, for example, when there are many endemic species [4, 25]. In the following the categories (i.e., peculiarity degrees), in roman numeral, are ordered according to decreasing peculiarity-I: regional endemic species; II: Italian species; IIIm, Mediterranean and Euro-Mediterranean species; III: European species; IV: Euro-Asiatic, Euro-Siberian species; and V: Palaearctic, Holarctic species. Such a classification was used with the exclusive intent of testing how the index performs. It is likely that it has no general value outside the Mediterranean basin, but it has the advantage that it is possible to outline the carabid chorological spectrum for any territorial unit (administrative, biogeographical, ecological, and geomorphological).

The categories I and II are the most peculiar biogeographical features of their territorial unit, because they represent a unique faunistic resource of that unit (i.e., endemic species) or of that geographical area (Italian species). Therefore, for achieving the aim of this paper these categories have been ranked at the highest degree of peculiarity.

The category IIIm includes the chorotypes linked to the Mediterranean basin (Euro-Mediterranean, circum-Mediterranean, Sicily-Maghreb, and so on). They were grouped in

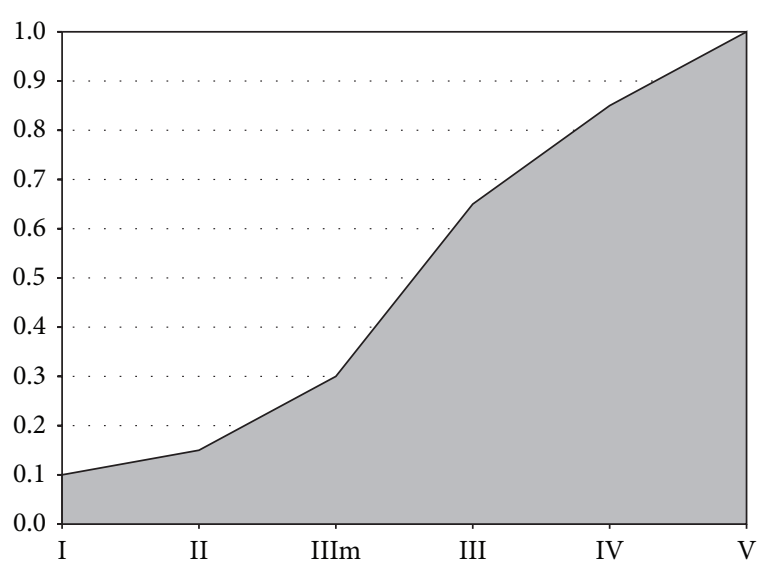

FIGURE 1: Graphical model of the biogeographical peculiarity (GMBP) based on a cumulative sum where the relative abundance of each chorological category has been summed starting from the most peculiar one and including all the amounts that have been added previously $\left(\mathrm{IBP}^{\prime}=0.92\right)$.

a separate category for reasons of peculiarity, because the main part of the Italian territory is in the middle of the Mediterranean basin, which is characterized by a particular biogeographical history [39-44]; hence just for the purpose of this example the IIIm category has been considered a little more peculiar to the Italian fauna than category III.

As a second step to compute the index, it is necessary to outline an operational ecological unit (OEU), where it will be possible to analyse the biogeographical spectrum. Administrative, hydrological (catchment), or ecological (CORINE habitats and ecosystems) criteria may be followed for drawing the boundaries of the unit.

These steps are similar to those described in $[30,35]$ in studies of environmental evaluation for conservation.

2.2. The Index of the Biogeographical Peculiarity (IBP). The relative abundance of each chorological category inside any $\mathrm{OEU}$ is given by the ratio of species belonging to that category to the number of species living in the OEU. A finite number of species live in any OEU, and there could be some chorological category that is not represented by that species. This means that, for example, if the fauna of a given OEU has been populated by the IV and $\mathrm{V}$ categories over time, then that fauna is not peculiar to that OEU. Conversely, if that OEU was a speciation site or a confinement site for geographical relicts, then its fauna may be marked by many endemic species; hence that fauna has high degree of peculiarity to that OEU.

In Figure 1 the chorological diversity of a hypothetical OEU is depicted by drawing a graphical model of the biogeographical peculiarity (GMBP) where the relative abundance of each chorological category was summed, starting from the most peculiar one and including all the amounts that were added previously (see Table 1 for the detailed computation steps). From a mathematical point of view, it is possible to evaluate such a graphical model, by a cumulative sum $(A)$, 
TABLE 1: Rank ord.: rank order of the categories; chor.cat.: chorological categories; rel.ab.: relative abundance of each category; GMBP: step by step cumulative sum (left) for getting the numbers (right) used to draw the Graphical Model of Biogeographical Peculiarity (Figure 1); IBP' sum (first six cells) and computation (bottom separate cells) of the Index of Biogeographical Peculiarity (in bold).

\begin{tabular}{lcclc}
\hline Rank ord. & Chor.cat. & Rel.ab. & GMBP & IBP' \\
\hline 6 & I & .1 & .1 & $.1+$ \\
5 & II & .05 & $.1+.05=.15$ & $.15+$ \\
4 & IIIm & .15 & $.1+.05+.15=.3$ & $.3+$ \\
3 & III & .35 & $.1+.05+.15+.35=.65$ & $.65+$ \\
2 & IV & .2 & $.1+.05+.15+.35+.2=.85$ & $.85+$ \\
1 & V & .15 & $.1+.05+.15+.35+.2+.15=1$ & 3.05 \\
\hline & & & $(3.05-1) /(6-1)=.41$ \\
& & & $(.41+6) /(1+6)=.92$ \\
\hline
\end{tabular}

TABLE 2: Hypothesized scenario for the IBP. Several cases have been hypothesized in the OEUs from la to 6, that is, from the highest to the lowest number of endemic species. To get consistent values of peculiarity the IBP must be weighed, so that the value of each chorological spectrum is gradually decreasing from la to 6. If the IBP is computed following [3] it fluctuates from la to 6 with inconsistent values (e.g., 2a versus $2 \mathrm{~b}$ ), while the $\mathrm{IBP}^{\prime}$ gradually decreases from la to 6 following the gradient of decreasing peculiarity.

\begin{tabular}{|c|c|c|c|c|c|c|c|c|c|c|c|c|c|c|c|c|c|c|c|c|c|c|c|}
\hline \multirow{2}{*}{$\begin{array}{l}\text { Rank } \\
\text { ord. }\end{array}$} & \multirow{2}{*}{$\begin{array}{c}\text { Cases } \\
\text { chor.cat. }\end{array}$} & \multicolumn{2}{|c|}{ la } & \multicolumn{2}{|c|}{$1 b$} & \multicolumn{2}{|c|}{$2 \mathrm{a}$} & \multicolumn{2}{|c|}{$2 b$} & \multicolumn{2}{|c|}{$3 a$} & \multicolumn{2}{|c|}{$3 b$} & \multicolumn{2}{|c|}{$4 \mathrm{a}$} & \multicolumn{2}{|c|}{$4 b$} & \multicolumn{2}{|c|}{$5 a$} & \multicolumn{2}{|c|}{$5 b$} & \multicolumn{2}{|c|}{6} \\
\hline & & $\%$ & $\Sigma$ & $\%$ & $\Sigma$ & $\%$ & $\Sigma$ & $\%$ & $\Sigma$ & $\%$ & $\Sigma$ & $\%$ & $\Sigma$ & $\%$ & $\Sigma$ & $\%$ & $\Sigma$ & $\%$ & $\Sigma$ & $\%$ & $\Sigma$ & $\%$ & $\Sigma$ \\
\hline 6 & I & 1 & 1 & 0.10 & 0.10 & 0 & 0 & 0 & 0 & 0 & 0 & 0 & 0 & 0 & 0 & 0 & 0 & 0 & 0 & 0 & 0 & 0 & 0 \\
\hline 5 & II & 0 & 1 & 0 & 0.1 & 1 & 1 & 0.01 & 0.01 & 0 & 0 & 0 & 0 & 0 & 0 & 0 & 0 & 0 & 0 & 0 & 0 & 0 & 0 \\
\hline 4 & IIIm & 0 & 1 & 0 & 0.1 & 0 & 1 & 0 & 0.01 & 1 & 1 & 0.01 & 0.01 & 0 & 0 & 0 & 0 & 0 & 0 & 0 & 0 & 0 & 0 \\
\hline 3 & III & 0 & 1 & 0 & 0.1 & 0 & 1 & 0 & 0.01 & 0 & 1 & 0 & 0.01 & 1 & 1 & 0.01 & 0.01 & 0 & 0 & 0 & 0 & 0 & 0 \\
\hline 2 & IV & 0 & 1 & 0 & 0.1 & 0 & 1 & 0 & 0.01 & 0 & 1 & 0 & 0.01 & 0 & 1 & 0 & 0.01 & 1 & 1 & 0.01 & 0.01 & 0 & 0 \\
\hline \multirow[t]{4}{*}{1} & $\mathrm{~V}$ & 0 & 1 & 0.9 & 1 & 0 & 1 & 0.99 & 1 & 0 & 1 & 0.99 & 1 & 0 & 1 & 0.99 & 1 & 0 & 1 & 0.99 & 1 & 1 & 1 \\
\hline & IBP & \multicolumn{2}{|c|}{1} & \multicolumn{2}{|c|}{0.100} & \multicolumn{2}{|c|}{0.800} & \multicolumn{2}{|c|}{0.008} & \multicolumn{2}{|c|}{0.600} & \multicolumn{2}{|c|}{0.006} & \multicolumn{2}{|c|}{0.4} & \multicolumn{2}{|c|}{0.004} & \multicolumn{2}{|c|}{0.200} & \multicolumn{2}{|c|}{0.002} & \multicolumn{2}{|c|}{0.000} \\
\hline & wIBP & \multicolumn{2}{|c|}{7} & \multicolumn{2}{|c|}{6.1} & \multicolumn{2}{|c|}{5.8} & \multicolumn{2}{|c|}{5.01} & \multicolumn{2}{|c|}{4.6} & \multicolumn{2}{|c|}{4.0} & \multicolumn{2}{|c|}{3.4} & 3. & & 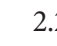 & & 2. & & 1. & 0 \\
\hline & $\mathrm{IBP}^{\prime}$ & 1 & 1 & 0. & 87 & & & & & & & 0.5 & & & & 0. & & 0.3 & 31 & & & 0.1 & 14 \\
\hline
\end{tabular}

which is in direct relation to the number of endemic species (i.e., peculiarity) as follows:

$$
A=\left(\sum_{j=1}^{n c} \sum_{i=1}^{j} X_{i}\right)-1,
$$

where " $X_{i}$ " is the relative abundance of each chorological category (i.e., ratio of species belonging to that category to the total number of species) and " $n c$ " is the number of chorological categories (the last category will always add up to over 1 , and it is not depicted by an area in the graph, which is why 1 is subtracted).

It is easy to link the grey area of Figure 1 to an index of the biogeographical peculiarity (IBP), ranging between 0 and 1 and directly related to the categories most characterizing the OEU fauna (i.e., endemic species in our example).

The maximum value of $A$ is reached when all the species belong to the most peculiar category

$$
A_{\text {max }}=n c-1 \text {; }
$$

therefore the IBP is

$$
\mathrm{IBP}=\left(\frac{A}{A_{\max }}\right) .
$$

In this way the IBP is directly linked to the chorotype that enhances the biogeographical peculiarity. Furthermore, by simply multiplying the IBP by 100 we would get the percentage of peculiarity. The steps for drawing Figure 1 and its related IBP have been summarized in Table 1 .

Worth of attention is the fact that as a consequence of the properties of numerical series IBP gives comparable values when different OEUs are made by the same categories, while it is possible to get biogeographically inconsistent values when the maximum peculiarity category is not the same in the different OEUs, as clearly shown in Table 2.

To get comparable values from any chorological spectrum the IBP must be weighed, so that, for example, a chorological spectrum with at least one endemic species is ranked higher than a chorological spectrum made with all category II species, while the latter gets an intermediate rank between the first spectrum and a spectrum made with all category IIIm species, and so on for as much as the number of categories.

An effective weighing rule is to add the rank order of the most peculiar category to IBP. Several cases have been hypothesized in Table 2, where, for example, in case $2 \mathrm{~b}$ there are species belonging to categories II and V, thus II being the most peculiar and in 5 th position ( $\mathrm{V}$ is in the 1 st position and I is in the 6 th position); 5 will be added to the computed IBP 
TABLE 3: Carabid species in eight sample sites of the Mediterranean bioclimatic region. Column headings with Le: holm oak, while Su: cork oak. Ci: Mediterranean short bushes. Choro.: chorological category. Mean: mean percentage value of each category. I: information value of each category and Evenness value ( $E$, bottom cell).

\begin{tabular}{|c|c|c|c|c|c|c|c|c|c|c|}
\hline Sclerophyllous forests & Le & Sul & Su2 & TLe2 & TCi & TLe3 & TLe4 & TLeQ & & Choro. \\
\hline Abax ater curtulus Fairmaire, 1856 & 1 & & & & & & & & & III \\
\hline Amara fusca Dejean, 1828 & & & & & 1 & & & & & IV \\
\hline Brachinus brevicollis Motschulsky, 1844 & & 1 & & & & & & & & IV \\
\hline Brachinus crepitans (Linné, 1758) & & 1 & & & & & & & & $\mathrm{~V}$ \\
\hline Calathus cinctus Motschulsky, 1850 & 1 & & & & 1 & & & & & $\mathrm{~V}$ \\
\hline Calathus fuscipes latus Serville, 1821 & & & 1 & & 1 & & & 1 & & IIIm \\
\hline Calathus montivagus Dejean 1831 & 1 & 1 & 1 & 1 & 1 & 1 & 1 & 1 & & II \\
\hline Calosoma sycophanta (Linné, 1758) & & & & & 1 & & 1 & 1 & & $\mathrm{~V}$ \\
\hline Carabus convexus convexus Fabricius, 1775 & & & & & & & 1 & & & IV \\
\hline Carabus coriaceus mediterraneus Born, 1906 & & & & 1 & 1 & & & & & III \\
\hline Carabus lefebvrei lefebvrei Dejean, 1826 & & 1 & 1 & & & & & & & II \\
\hline Cychrus italicus Bonelli, 1809 & 1 & & & & & & & & & II \\
\hline Cymindis axillaris (Fabricius, 1794) & & & & & 1 & & & & & $\mathrm{~V}$ \\
\hline Harpalus attenuatus Stephens, 1828 & & 1 & & & & & & & & IIIm \\
\hline Harpalus rubripes (Duftschmid, 1812) & & 1 & 1 & & & & & & & IV \\
\hline Harpalus sulphuripes sulphuripes Germar, 1824 & & 1 & & & 1 & & & & & IIIm \\
\hline Laemostenus cimmerius cimmerius (Fischer-Waldheim, 1823) & & & & & 1 & & & & & IIIm \\
\hline Masoreus wetterhallii wetterhallii (Gyllenhal, 1813) & & 1 & 1 & & & & & & & $\mathrm{~V}$ \\
\hline Microderes scaritides Sturm, 1818 & & & & & 1 & & & & & IV \\
\hline Microlestes luctuosus Holdhaus, 1904 & & & & & 1 & & & & & IV \\
\hline Nebria brevicollis (Fabricius, 1792) & & 1 & & & & & & & & IV \\
\hline Nebria kratteri Dejean, 1831 & & & & 1 & & & & 1 & & III \\
\hline Notiophilus rufipes Curtis, 1829 & & 1 & & & & 1 & 1 & 1 & & III \\
\hline Ophonus pumilio (Dejean, 1829) & & & & & 1 & & & & & IIIm \\
\hline Percus bilineatus (Dejean, 1828) & 1 & 1 & & & & & & & & II \\
\hline Platyderus neapolitanus jannonei Binaghi in Magistretti, 1955 & & 1 & 1 & & 1 & & 1 & 1 & & II \\
\hline Pseudomasoreus canigoulensis (Fairmaire \& Laboulbène, 1854) & & 1 & 1 & 1 & & & 1 & & & IIIm \\
\hline Pseudoophonus rufipes (Degeer, 1774) & & & & & & 1 & & & & $\mathrm{~V}$ \\
\hline Steropus melas italicus (Dejean, 1828) & & 1 & 1 & 1 & 1 & & & 1 & & III \\
\hline Trechus quadristriatus (Schrank, 1781) & & & & 1 & 1 & & & 1 & & IV \\
\hline \multirow[t]{2}{*}{ Species number } & 5 & 14 & 8 & 6 & 15 & 3 & 6 & 8 & & \\
\hline & & & & & & & & & Mean & $I$ \\
\hline $\mathrm{V}$ & 0,20 & 0,14 & 0,13 & 0 & 0,2 & 0,33 & 0,17 & 0,13 & 0,16 & 0,29 \\
\hline IV & 0 & 0,21 & 0,13 & 0,17 & 0,27 & 0 & 0,17 & 0,13 & 0,13 & 0,27 \\
\hline III & 0,20 & 0,14 & 0,13 & 0,50 & 0,13 & 0,33 & 0,17 & 0,38 & 0,25 & 0,35 \\
\hline IIIm & 0 & 0,21 & 0,25 & 0,17 & 0,27 & 0 & 0,17 & 0,13 & 0,15 & 0,28 \\
\hline II & 0,6 & 0,29 & 0,38 & 0,17 & 0,13 & 0,33 & 0,33 & 0,25 & 0,31 & 0,36 \\
\hline I & 0 & 0 & 0 & 0 & 0 & 0 & 0 & 0 & 0 & 0 \\
\hline
\end{tabular}

of 0.008 , giving a weighed wIBP $=5.008$. Consequently, the new weighed maximum value will be

$$
\mathrm{w} A_{\text {max }}=\mathrm{IBP}_{\text {max }}+n c=1+n c ;
$$

therefore the new $\mathrm{IBP}^{\prime}$ will be

$$
\mathrm{IBP}^{\prime}=\frac{\mathrm{wIBP}}{\mathrm{w} A_{\max }},
$$

and in our example $\mathrm{IBP}^{\prime}=5.008 / 7=0.72$.
An application example of the IBP is given using real data from 16 sample sites located in two different types of ecosystems (i.e., two OEUs) in the Calabria region of southern Italy [45]. In this case, the boundaries between OEUs are ecological and not geographical. Carabid beetles were sampled with pitfall traps. Eight samples were collected in Mediterranean sclerophyllous forests (holm and cork oak), while the others were collected in oro-Mediterranean beech forests (Tables 3 and 4). The mean relative abundance in 
TABLE 4: Carabid species in eight beech forests. Column headings: different localities and same vegetation. Choro.: chorological category. Mean: mean percentage value of each category. $I$ : information value of each category and Evenness value ( $E$, bottom cell).

\begin{tabular}{|c|c|c|c|c|c|c|c|c|c|c|}
\hline Beech & $\mathrm{Fa} 3$ & $\mathrm{Fa} 2$ & $\mathrm{Fa}$ & AsF & AF3 & AF1 & $\mathrm{AbF}$ & AF2 & & Choro. \\
\hline Abax ater curtulus Fairmaire, 1856 & 1 & 1 & 1 & 1 & 1 & 1 & & & & III \\
\hline Paranchus albipes (Fabricius, 1796) & & & & & 1 & & & & & $\mathrm{~V}$ \\
\hline Bothriopterus quadrifoveolatus (Letzner, 1852) & & & & & & 1 & & & & III \\
\hline Metallina lampros (Herbst, 1784) & & & & & & & 1 & & & $\mathrm{~V}$ \\
\hline Ocydromus latinus (Netolitzky, 1911) & & & & & & & & 1 & & III \\
\hline Calathus fracassii fracassii Heyden, 1908 & & & & & & 1 & 1 & & & II \\
\hline Calathus fuscipes latus Serville, 1821 & & 1 & & 1 & 1 & & & 1 & & IIIm \\
\hline Calathus montivagus Dejean 1831 & 1 & 1 & 1 & 1 & 1 & 1 & 1 & 1 & & II \\
\hline Calathus piceus (Marsham, 1802) & 1 & & 1 & 1 & 1 & 1 & 1 & 1 & & III \\
\hline Carabus convexus convexus Fabricius, 1775 & 1 & 1 & 1 & & 1 & & & 1 & & IV \\
\hline Carabus lefebvrei lefebvrei Dejean, 1826 & 1 & 1 & 1 & 1 & & 1 & 1 & 1 & & II \\
\hline Carabus preslii neumeyeri Schaum, 1856 & 1 & 1 & 1 & & 1 & 1 & 1 & 1 & & III \\
\hline Cychrus italicus Bonelli, 1809 & 1 & 1 & 1 & & 1 & 1 & 1 & & & II \\
\hline Leistus fulvibarbis fulvibarbis Dejean, 1826 & & & & & & 1 & & & & IIIm \\
\hline Leistus spinibarbis fiorii Lutshnik, 1913 & 1 & 1 & & & & & & 1 & & III \\
\hline Nebria kratteri Dejean, 1831 & 1 & 1 & 1 & 1 & 1 & 1 & 1 & 1 & & III \\
\hline Notiophilus biguttatus (Fabricius, 1779) & & & & & & & & 1 & & $\mathrm{~V}$ \\
\hline Notiophilus rufipes Curtis, 1829 & & & & & & 1 & & & & III \\
\hline Ophonus jeanneli Sciaky, 1987 & 1 & & & & & & & & & III \\
\hline Platyderus neapolitanus jannonei Binaghi in Magistretti, 1955 & 1 & 1 & 1 & & 1 & 1 & 1 & & & II \\
\hline Haptoderus apenninus (Dejean, 1831) & & & & & 1 & 1 & 1 & 1 & & II \\
\hline Platysma nigrita (Paykull, 1790) & & & 1 & & & & & & & $\mathrm{~V}$ \\
\hline Steropus melas italicus (Dejean, 1828) & & & 1 & 1 & & & & & & III \\
\hline Pterostichus micans Heer, 1841 & & 1 & & & & & & & & II \\
\hline Pterostichus ruffoi Sciaky, 1986 & & & & & & 1 & 1 & 1 & & $\mathrm{I}$ \\
\hline Synuchus vivalis (Illiger, 1798) & 1 & & & & & & & & & IV \\
\hline Trechus quadristriatus (Schrank, 1781) & 1 & & & & & & & & & IV \\
\hline Trichotichnus nitens (Heer, 1838) & & & 1 & & & & & & & III \\
\hline \multirow[t]{2}{*}{ Species number } & 13 & 11 & 12 & 7 & 11 & 14 & 11 & 12 & & \\
\hline & & & & & & & & & Mean & $I$ \\
\hline $\mathrm{V}$ & 0 & 0 & 0,08 & 0 & 0,09 & 0 & 0,09 & 0,08 & 0,04 & 0,14 \\
\hline IV & 0,23 & 0,09 & 0,08 & 0 & 0,09 & 0 & 0 & 0,08 & 0,07 & 0,19 \\
\hline III & 0,46 & 0,36 & 0,50 & 0,57 & 0,36 & 0,43 & 0,27 & 0,42 & 0,42 & 0,36 \\
\hline IIIm & 0 & 0,09 & 0 & 0,14 & 0,09 & 0,07 & 0 & 0,08 & 0,06 & 0,17 \\
\hline II & 0,31 & 0,45 & 0,33 & 0,29 & 0,36 & 0,43 & 0,55 & 0,25 & 0,37 & 0,37 \\
\hline I & 0 & 0 & 0 & 0 & 0 & 0,07 & 0,09 & 0,08 & 0,03 & 0,11 \\
\hline
\end{tabular}

the sites was evaluated for each chorological category and used to compute the Evenness Index (i.e., the ratio between the information content and the maximum possible information; see Tables 3 and 4) and the IBP.

\section{Results}

Table 2 shows a possible scenario of the index variation from complete peculiarity (case 1a) to lack of peculiarity (case 6). In the examples of Table 2 there are six chorological categories, with rank order ranging from 6 for the most peculiar (I) to 1 for the least peculiar (V), so that the chorological spectra including category I will be weighed by adding the value of 6 , while spectra including at most category II will be weighed by adding the value of 5 , and so on ending with spectra made with category $\mathrm{V}$ that will be weighed by adding the value of 1 . In Table 2 it is possible to see that the values of IBP fluctuate from left to right, while IBP' gradually decreases consistently with decreasing peculiarity from case la to case 6 .

A cumulative sum and a chart were linked to each sampled OEU, as in Figures 2 and 3. In sclerophyllous forests the weight of the categories ranges between 0.13 and 0.31 , while in beech forests the range is between 0.04 and 0.42 (see Tables 3 and 4). Weights are more evenly 


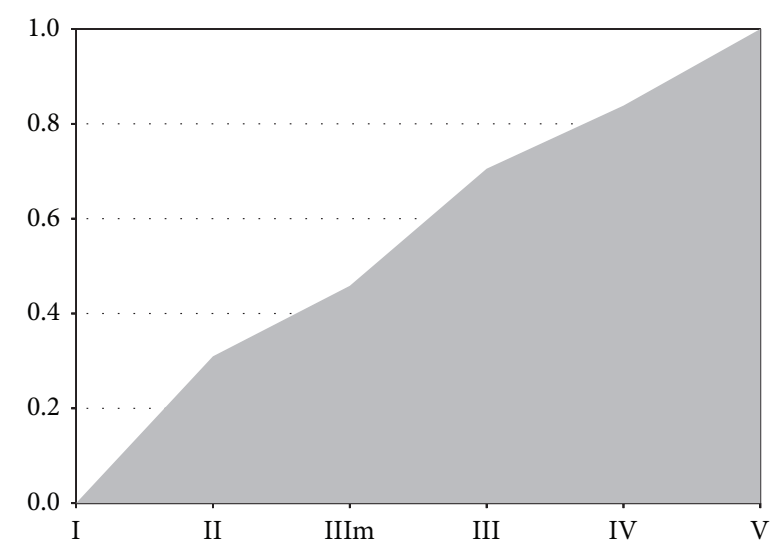

FIGURE 2: Graphical model of the biogeographical peculiarity in the sclerophyllous forests of Table $3\left(\mathrm{IBP}^{\prime}=0.78\right)$.

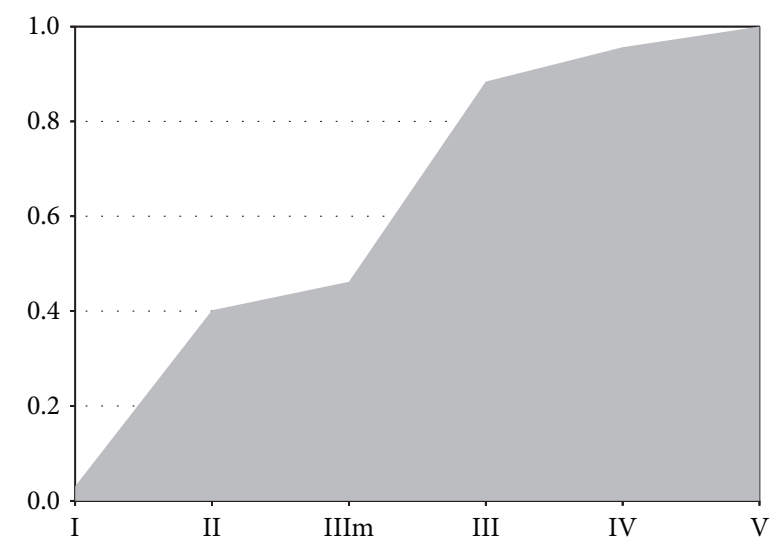

FIGURE 3: Graphical model of the biogeographical peculiarity in the beech forests of Table $4\left(\mathrm{IBP}^{\prime}=0.94\right)$.

distributed among categories in the sclerophyllous forests than in the beech forests, as confirmed by the Evenness Index, which is 0.87 for the former, while it is 0.74 for the latter. The Evenness is mirrored also by the graphical model of the biogeographical peculiarity, as the sclerophyllous chart (Figure 2) rises gradually to 1 , while the beech chart (Figure 3 ) is broken into two steps with increasing steepness among the breaks.

Figures 2 and 3 show that the Italian endemic species, together with European species, are more abundant in beech forests than in sclerophyllous ones, while Mediterranean species are more abundant in sclerophyllous forests. Only a few species with a wide distribution range (categories IV and V) colonized mountain environments, while they are as abundant as Mediterranean species in sclerophyllous forests.

The species composition is mirrored by the IBP of each ecosystem. The IBP ${ }^{\prime}$ is higher where the fauna was populated by more peculiar species, that is, beech forests $\left(\mathrm{IBP}^{\prime}=0.94\right)$, where the index is $16 \%$ points higher than in sclerophyllous forests $\left(\mathrm{IBP}^{\prime}=0.78\right)$.

The index has also been calculated for each sampled site; two series of eight values have been obtained and then statistically compared by the $U$ test. The $\mathrm{IBP}^{\prime}$ is significantly different for the two ecosystems $\left(U=9, n_{1}=n_{2}=8\right.$, and $P=0.02$ ).

To get a very high degree of peculiarity in beech forests there should have been fewer European species (category III) and a significant number of endemic species (category I).

\section{Discussion}

The index of biogeographical peculiarity gives a new method for integrating in a single measure of peculiarity the chorological spectrum characterizing the present species composition of a given OEU. This means that the IBP takes into account the relative weight of every chorological category, that under a biological point of view means to give a value to the whole biogeographical history of a given OEU and not only to the endemism phenomenon alone. As a consequence, total species richness of the OEUs will have an influence on the IBP, because if, for example, two OEUs sheltering the same number of endemic species differ in species richness, then the OEU with the higher species richness will probably have smaller IBP. This is a property the index was intended for.

Another property lies in the possibility to compare the peculiarity of different OEUs belonging to similar biogeographical areas. The application of the index at the local scale is needed because the characterization of the species is based on chorological categories that should be common. Furthermore this index is adaptable, because different operational units can be chosen, either administrative boundaries or biogeographical units or surfaces.

From a mathematical point of view, the most important factor influencing the index variability is the order of the chorological category weights, because if the highest weights are found at the beginning of the numerical series then the IBP $^{\prime}$ will have high values, while the opposite case will lead to low IBP' values. The IBP is a value linked with a numerical series, but complex mathematical operations are needed to link numerical series with a single value; this is why the mathematical simplicity of the IBP is limited by the fact that any IBP is linked to a set of graphs slightly different from each other (i.e., the curves smooth in slightly different ways), while the GMBP is unique for each chorological spectrum. As a general rule, the higher the $\mathrm{IBP}^{\prime}$, the higher the contribution of the categories leftward of the ordinal sequence ( $x$-axis). The highest IBP ${ }^{\prime}$ is reached when all the species belong to the leftmost category.

This method can be accurately applied to areas with a complete knowledge of the biota in question, since a unique new record of an endemic species can change the score; moreover the significance among small differences of the index must be interpreted under a biogeographical rather than numerical perspective.

As outlined by [23] an index should not be used as an a priori tool in biogeographical studies, because living organisms are characterised by different bioevolutionary features. We think that the chorological spectrum of a given region is strongly affected by the biogeographical history of that region, whose understanding should be framed into the 
processes of speciation, extinction, and population dynamic [10]. The comparison of different $\mathrm{IBP}^{\prime}$ values may be an aid in such understanding, as for the above example where carabid species belonging to category II have been found to be very abundant in beech forests. It is possible that this is a consequence of the glacial ages, which exerted a strong influence on the dispersal of living organisms by pushing species southward along the Italian peninsula [46, 47]. Then, during interglacial periods, the cold-preferring fauna was forced to find shelter upward either latitudinally or altitudinally on the mountains, where some species evolved to endemic status. In the coastal part of the Calabria, the new (in the sense that it appeared during the Pleistocenic era) biome of the Mediterranean sclerophyllous forest was colonized by widely tolerant species with a wide geographical range. Palaeoclimatic circumstances gave rise to a more peculiar fauna in temperate montane environments than in the Mediterranean belt. This greater peculiarity is clearly mirrored by the $\mathrm{IBP}^{\prime}$ values.

Spatiotemporal features of chorotypes are the result of evolutionary events as well as of proximate causes [48], and focusing on the typology of the chorotype (e.g., local, regional, and national endemism) should give more insight into the global nature of spatial variation in geographic range sizes and a better understanding of how these relate to ecosystems $[49,50]$. This means that it is possible to adapt or to improve the index with chorotypes tailored to the particular features (if any) of the studied territory.

The index is useful not only to outline the faunistic or floristic history of a region but also to highlight the concentration of endemic species for addressing conservation priorities [51]. This is why it can be used to evaluate biotic homogenization [52], because it is sensitive to the incoming of allochthonous species, which change the chorological spectrum. Allochthonous species are clearly the less peculiar ones, so that they must be placed near the end of $x$-axis, even by adding a new category if necessary. Furthermore, the graphical model linked to the IBP may be used to monitor temporal changes towards homogenization or differentiation or for hypothesizing future scenarios to optimize broad-scale surveillance of invasive species [17], either in the case of the spreading of individual species [53] or when native versus nonnative species interaction has to be evaluated [54].

From a general point of view, evaluation for conservation should be based not simply on species richness but also on species life strategies. The chorotype of a species either mirrors its adaptive pathway, because it is the manifestation of complex interactions between species' niche and environmental pressures [55], or is a short-term response at the population level [56]. This is why it is indirectly related to species life strategies. The IBP' which synthesizes the set of chorotypes of a given region could be used for studies integrating ecology and biogeography [57] or for paralleling analysis from a hotspots approach [58] or for monitoring conservation efficiency in priority areas for conservation [59].

In the light of some global change monitoring approaches based on species range study (e.g., global coherence approach [60]; global versus local diversity variation [61]; projecting models of current species range [62]), policies focusing on multispecies management could be helped by applying one evaluation index (i.e., the $\mathrm{IBP}^{\prime}$ ) for comparing plants and animals responses to climate variation.

\section{Conflict of Interests}

The authors declare that there is no conflict of interests regarding the publication of this paper.

\section{References}

[1] R. S. Dodd and Z. Afzal Rafii, "Evolutionary genetics of mangroves: continental drift to recent climate change," Trees, vol. 16, no. 2-3, pp. 80-86, 2002.

[2] A. Tribsch and P. Schönswetter, "Patterns of endemism and comparative phylogeography confirm palaeoenvironmental evidence for Pleistocene refugia in the Eastern Alps," Taxon, vol. 52, no. 3, pp. 477-497, 2003.

[3] B. Krystufek, E. V. Buzan, W. F. Hutchinson, and B. Hänfling, "Phylogeography of the rare Balkan endemic Martino's vole, Dinaromys bogdanovi, reveals strong differentiation within the western Balkan Peninsula," Molecular Ecology, vol. 16, no. 6, pp. 1221-1232, 2007.

[4] E. C. Pielou, Biogeograpy, Krieger, Malabar, Fla, USA, 1st edition, 1992.

[5] J. J. Wiens and M. J. Donoghue, "Historical biogeography, ecology and species richness," Trends in Ecology and Evolution, vol. 19, no. 12, pp. 639-644, 2004.

[6] M. Kirkpatrick and N. H. Barton, "Evolution of a species' range," The American Naturalist, vol. 150, no. 1, pp. 1-23, 1997.

[7] C. Finlayson, "Biogeography and evolution of the genus Homo," Trends in Ecology and Evolution, vol. 20, no. 8, pp. 457-463, 2005.

[8] G. C. Costa, C. Wolfe, D. B. Shepard, J. P. Caldwell, and L. J. Vitt, "Detecting the influence of climatic variables on species distributions: a test using GIS niche-based models along a steep longitudinal environmental gradient," Journal of Biogeography, vol. 35, no. 4, pp. 637-646, 2008.

[9] S. W. Punyasena, G. Eshel, and J. C. McElwain, "The influence of climate on the spatial patterning of Neotropical plant families," Journal of Biogeography, vol. 35, no. 1, pp. 117-130, 2008.

[10] K. J. Gaston, "Species-range size distributions: products of speciation, extinction and transformation," Philosophical Transactions of the Royal Society B, vol. 353, no. 1366, pp. 219-230, 1998.

[11] R. Pizzolotto, "Characterization of different habitats on the basis of the species traits and eco-field approach," Acta Oecologica, vol. 35, no. 1, pp. 142-148, 2009.

[12] H. T. Arita, F. Figueroa, A. Frisch, P. Rodríguez, and K. SantosDel-Prado, "Geographical range size and the conservation of Mexican mammals," Conservation Biology, vol. 11, no. 1, pp. 92100, 1997.

[13] G. Ceballos, P. R. Ehrlich, J. Soberón, I. Salazar, and J. P. Fay, "Global mammal conservation: what must we manage?" Science, vol. 309, no. 5734, pp. 603-607, 2005.

[14] R. J. Whittaker, M. B. Araújo, P. Jepson, R. J. Ladle, J. E. M. Watson, and K. J. Willis, "Conservation biogeography: assessment and prospect," Diversity and Distributions, vol. 11, no. 1, pp. 3-23, 2005. 
[15] N. Cooper, J. Bielby, G. H. Thomas, and A. Purvis, "Macroecology and extinction risk correlates of frogs," Global Ecology and Biogeography, vol. 17, no. 2, pp. 211-221, 2008.

[16] P. Brandmayr, T. Zetto, and R. Pizzolotto, in I Coleotteri Carabidi per la valutazione ambientale e la conservazione della biodiversità, APAT, Rome, Italy, 2005.

[17] R. Real, A. L. Márquez, A. Estrada, A. R. Muñoz, and J. M. Vargas, "Modelling chorotypes of invasive vertebrates in mainland Spain," Diversity and Distributions, vol. 14, no. 2, pp. 364-373, 2008.

[18] B. Y. Vilenkin and V. I. Chikatunov, "Participation of species with different zoogeographical ranks in the formation of local faunas: a case study," Journal of Biogeography, vol. 27, no. 5, pp. 1201-1208, 2000.

[19] C. M. Cartagena and E. Galante, "Loss of Iberian island tenebrionid beetles and conservation management recommendations," Journal of Insect Conservation, vol. 6, no. 2, pp. 73-81, 2002.

[20] S. W. Laffan and M. D. Crisp, "Assessing endemism at multiple spatial scales, with an example from the Australian vascular flora," Journal of Biogeography, vol. 30, no. 4, pp. 511-520, 2003.

[21] S. Lavergne, W. Thuiller, J. Molina, and M. Debussche, "Environmental and human factors influencing rare plant local occurrence, extinction and persistence: a 115-year study in the Mediterranean region," Journal of Biogeography, vol. 32, no. 5, pp. 799-811, 2005.

[22] C. A. Szumik, F. Cuezzo, P. A. Goloboff, and A. E. Chalup, "An optimality criterion to determine areas of endemism," Systematic Biology, vol. 51, no. 5, pp. 806-816, 2002.

[23] S. Fattorini, "Levels of endemism are not necessarily biased by the co-presence of species with different range sizes: a case study of Vilenkin and Chikatunov's models," Journal of Biogeography, vol. 34, no. 6, pp. 994-1007, 2007.

[24] M. D. Crisp, S. Laffan, H. P. Linder, and A. Monro, "Endemism in the Australian flora," Journal of Biogeography, vol. 28, no. 2, pp. 183-198, 2001.

[25] S. Anderson, "Area and endemism," The Quarterly Review of Biology, vol. 69, no. 4, pp. 451-471, 1994.

[26] J. F. Mota, F. J. Pérez-García, M. L. Jiménez Sánchez, J. J. Amate, and J. de Giles Penas, "Phytogeographical relationships among high mountain areas in the baetic ranges (South Spain)," Global Ecology and Biogeography, vol. 11, no. 6, pp. 497-504, 2002.

[27] T. Kull and M. J. Hutchings, "A comparative analysis of decline in the distribution ranges of orchid species in Estonia and the United Kingdom," Biological Conservation, vol. 129, no. 1, pp. 3139, 2006.

[28] A. V. Taglianti, A. Audisio, M. Biondi, M. Bologna, G. Carpaneto, A. De Biase et al., "A proposal for a chorotype classification of the Near East fauna, in the framework of the Western Palearctic region," Biogeographia, vol. 20, pp. 31-59, 1999.

[29] H. Turin, L. Penev, and A. Casale, The Genus Carabus in Europe: A Synthesis, Pensoft, Sofia, Bulgaria, 2003.

[30] R. Pizzolotto and P. Brandmayr, "An index to evaluate landscape conservation state based on land-use pattern analysis and geographic information system techniques," Coenoses, vol. 11, no. 1, pp. 37-44, 1996.

[31] L. Xiu-zhen, X. Du-ning, H. Yuan-man, and W. Xian-li, "Effect of spatial pattern on nutrient reduction in the liaohe delta," Journal of Geographical Sciences, vol. 11, no. 3, pp. 336-349, 2001.

[32] F. Catani, B. Lastrucci, and S. Moretti, "Sustainability of water and natural resources management: an integrated approach," Progress in Water Resources, vol. 8, pp. 411-420, 2003.
[33] C. Ricotta, M. Marignani, F. Campaiola, G. C. Avena, and C. Blasi, "A partial order approach for summarizing landscape quality," Community Ecology, vol. 4, no. 2, pp. 121-127, 2003.

[34] C. Blasi, L. Zavattero, M. Marignani et al., "The concept of land ecological network and its design using a land unit approach," Plant Biosystems, vol. 142, no. 3, pp. 540-549, 2008.

[35] C. Ferrari, G. Pezzi, L. Diani, and M. Corazza, "Evaluating landscape quality with vegetation naturalness maps: an index and some inferences," Applied Vegetation Science, vol. 11, no. 2, pp. 243-250, 2008.

[36] C. Guarino, S. Santoro, and L. De Simone, "Assessment of vegetation and naturalness: a study case in Southern Italy," iForest, vol. 1, pp. 114-121, 2008.

[37] P. Di Marzio, P. Di Martino, L. Mastronardi, P. Fortini, C. Giancola, and V. Viscosi, "Analisi integrata socio-economica e di copertura del suolo in un paesaggio a prevalente matrice agricola," Italian Journal of Agronomy, vol. 3, pp. 47-52, 2009.

[38] M. Bodesmo, L. Pacicco, B. Romano, and A. Ranfa, “The role of environmental and socio-demographic indicators in the analysis of land use changes in a protected area of the Natura 2000 Network: the case study of Lake Trasimeno, Umbria, Central Italy," Environmental Monitoring and Assessment, vol. 184, no. 2, pp. 831-843, 2012.

[39] W. Schule, "Mammals, vegetation and the initial human settlement of the Mediterranean islands: a palaeoecological approach," Journal of Biogeography, vol. 20, no. 4, pp. 399-412, 1993.

[40] R. Verlaque, F. Médail, P. Quézel, and J. Babinot, "Endemisme vegetal et paleogeographie dans le Bassin Mediterraneen," Geobios, vol. 30, supplement 2, pp. 159-166, 1997.

[41] F. Médail and P. Quézel, "Hot-spots analysis for conservation of plant biodiversity in the Mediterranean Basin," Annals of the Missouri Botanical Garden, vol. 84, no. 1, pp. 112-127, 1997.

[42] D. T. Bilton, P. M. Mirol, S. Mascheretti, K. Fredga, J. Zima, and J. B. Searle, "Mediterranean Europe as an area of endemism for small mammals rather than a source for northwards postglacial colonization," Proceedings of the Royal Society B, vol. 265, no. 1402, pp. 1219-1226, 1998.

[43] A. Pons and P. Quézel, "A propos de la mise en place du climat mediterraneen," Comptes Rendus De L'AcaDemie Des Sciences: Series IIA, vol. 327, no. 11, pp. 755-760, 1998.

[44] K. J. Willis and R. J. Whittaker, "The refugial debate," Science, vol. 287, no. 5457, pp. 1406-1407, 2000.

[45] R. Pizzolotto, P. Brandmayr, and A. Mazzei, "Carabid beetles in a Mediterranean region: biogeographical and ecological features," Report of the Danish Institute of Agricultural Sciences, vol. 114, pp. 243-254, 2005.

[46] M. La Greca, "Lorigine della fauna italiana," Le Scienze, vol. 187, pp. 66-79, 1984.

[47] D. Magri, G. G. Vendramin, B. Comps et al., "A new scenario for the quaternary history of European beech populations: palaeobotanical evidence and genetic consequences," New Phytologist, vol. 171, no. 1, pp. 199-221, 2006.

[48] J. Blondel and J. Vigne, "Space, time, and man as determinants of diversity of birds and mammals in the Mediterranean region," in Species Diversity in Ecological Communities, R. E. Ricklefs and D. Schluter, Eds., pp. 135-146, University of Chicago Press, Chicago, Ill, USA, 1993.

[49] R. Grenyer, C. D. L. Orme, S. F. Jackson et al., "Global distribution and conservation of rare and threatened vertebrates," Nature, vol. 444, no. 7115, pp. 93-96, 2006. 
[50] C. D. L. Orme, R. G. Davies, V. A. Olson et al., "Global patterns of geographic range size in birds," PLoS Biology, vol. 4, no. 7, pp. 1276-1283, 2006.

[51] G. Casazza, G. Barberis, and L. Minuto, "Ecological characteristics and rarity of endemic plants of the Italian Maritime Alps," Biological Conservation, vol. 123, no. 3, pp. 361-371, 2005.

[52] J. D. Olden, "Biotic homogenization: a new research agenda for conservation biogeography," Journal of Biogeography, vol. 33, no. 12, pp. 2027-2039, 2006.

[53] P. Pyšek, V. Jarošík, J. Müllerová, J. Pergl, and J. Wild, “Comparing the rate of invasion by heracleum mantegazzianum at continental, regional, and local scales," Diversity and Distributions, vol. 14, no. 2, pp. 355-363, 2008.

[54] F. Leprieur, O. Beauchard, B. Hugueny, G. Grenouillet, and S. Brosse, "Null model of biotic homogenization: a test with the European freshwater fish fauna," Diversity and Distributions, vol. 14, no. 2, pp. 291-300, 2008.

[55] J. H. Brown, G. C. Stevens, and D. M. Kaufman, "The geographic range: size, shape, boundaries, and internal structure," Annual Review of Ecology and Systematics, vol. 27, pp. 597-623, 1996.

[56] C. Parmesan, T. L. Root, and M. R. Willig, "Impacts of extreme weather and climate on terrestrial biota," Bulletin of the American Meteorological Society, vol. 81, no. 3, pp. 443-450, 2000.

[57] M. Crisp, "Biome assembly: what we know and what we need to know," Journal of Biogeography, vol. 33, no. 8, pp. 1332-1333, 2006.

[58] N. Myers, R. A. Mittermeler, C. G. Mittermeler, G. A. B. Da Fonseca, and J. Kent, "Biodiversity hotspots for conservation priorities," Nature, vol. 403, no. 6772, pp. 853-858, 2000.

[59] G. M. Harris, C. N. Jenkins, and S. L. Pimm, "Refining biodiversity conservation priorities," Conservation Biology, vol. 19, no. 6, pp. 1957-1968, 2005.

[60] C. Parmesan and G. Yohe, "A globally coherent fingerprint of climate change impacts across natural systems," Nature, vol. 421, no. 6918 , pp. 37-42, 2003.

[61] D. F. Sax and S. D. Gaines, "Species diversity: from global decreases to local increases," Trends in Ecology and Evolution, vol. 18, no. 11, pp. 561-566, 2003.

[62] J. O. Meynecke, "Effects of global climate change on geographic distributions of vertebrates in North Queensland," Ecological Modelling, vol. 174, no. 4, pp. 347-357, 2004. 

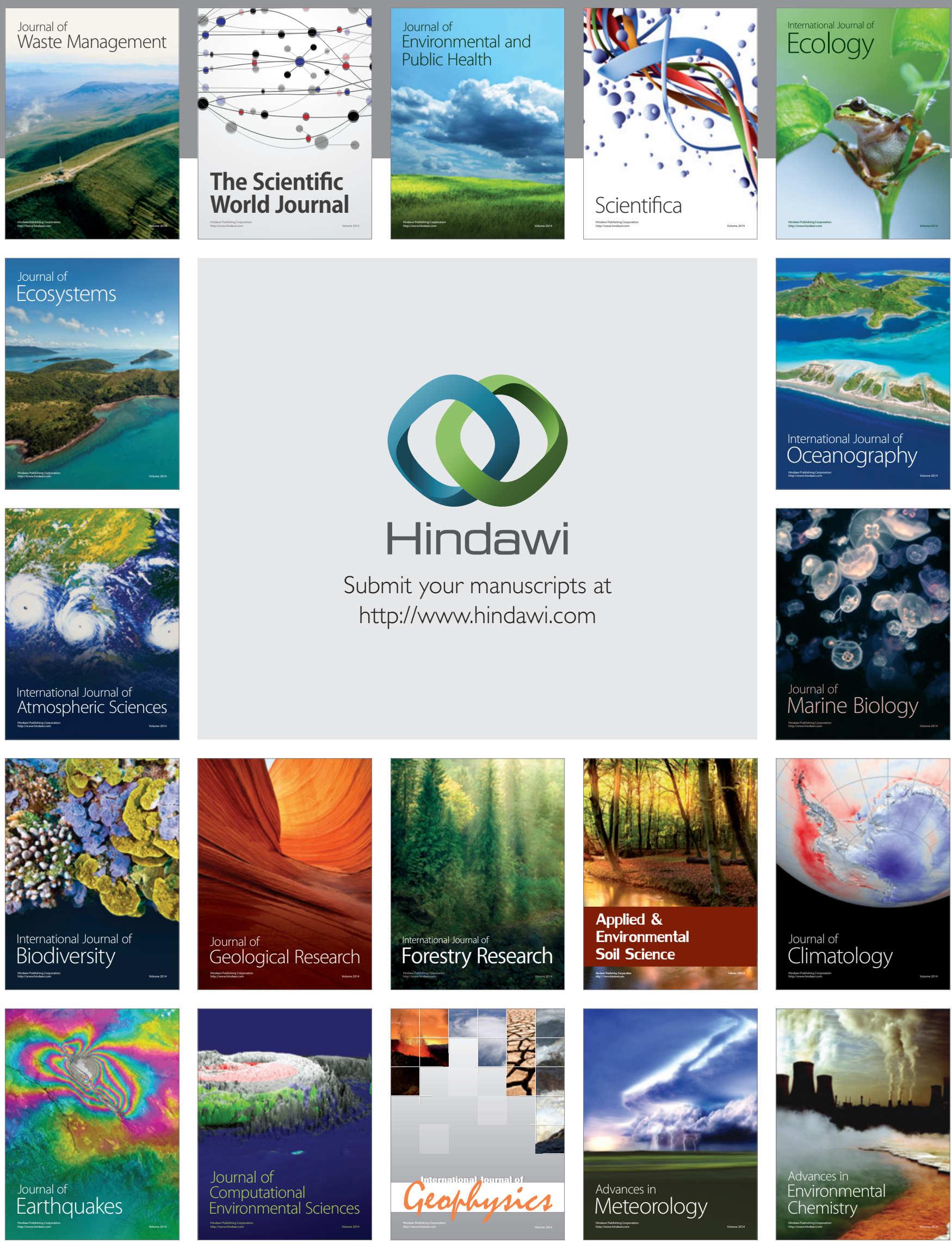